
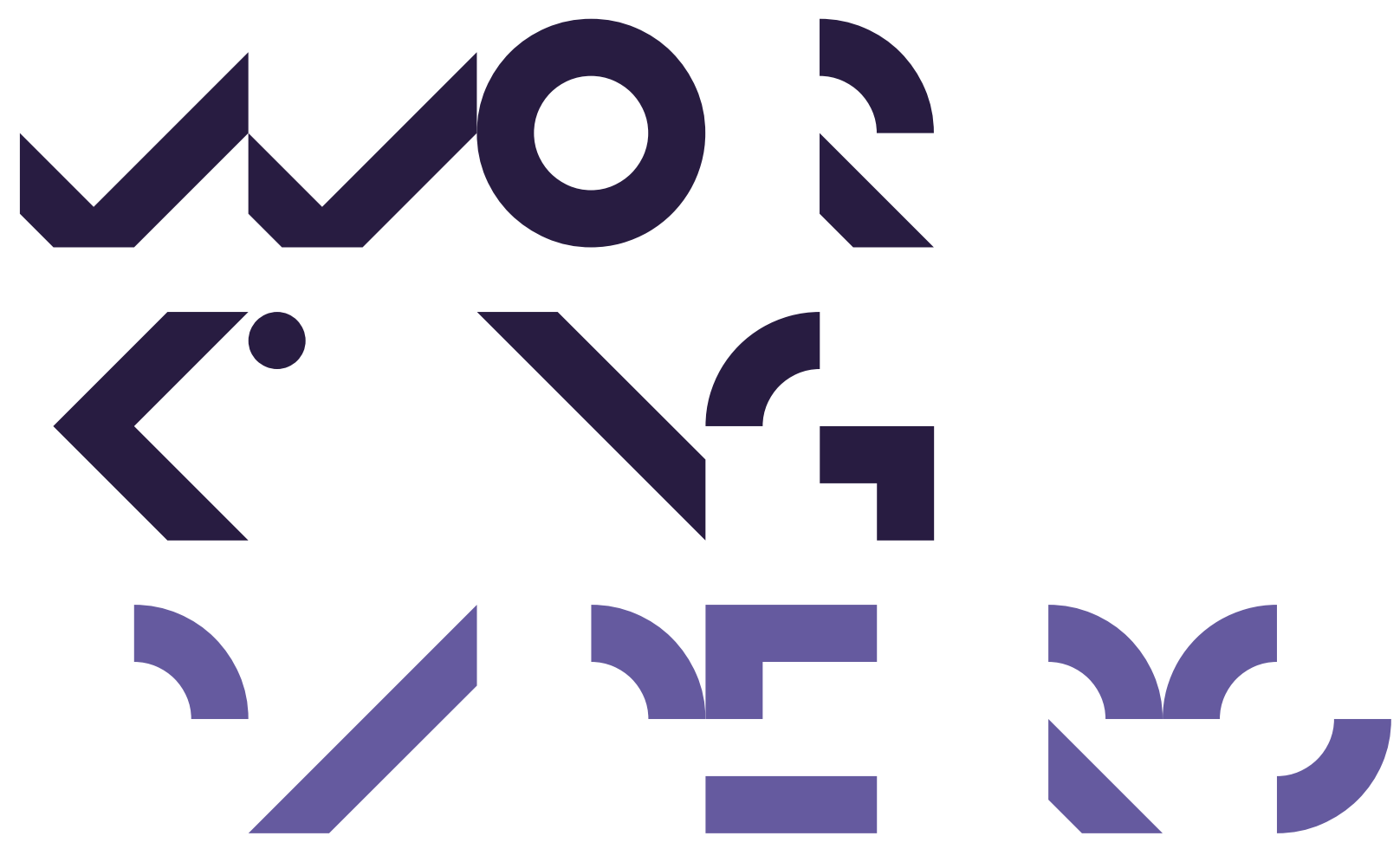

Economics Working Papers

2014-10

Advertising and concentration in the brewing industry

Erik Strøjer Madsen and Yanqing Wu 


\title{
Advertising and concentration in the brewing industry
}

\author{
Erik Strøjer Madsen and Yanqing Wu \\ University of Aarhus, School of Business and Social Sciences
}

\begin{abstract}
The opening of the markets in East Asia and Eastern Europe in the 1990s changed the structure of the beer markets and in the following years a large wave of mergers and acquisitions took place. The paper tracks the development in industry concentrations from 2002 to 2012, discusses some of the main drivers behind this development and points to economies of scale in advertising as a main pay-off from mergers and acquisitions. Using firm-level data both from the American market and the world market, the estimations verify significant economies of scale in marketing and distribution costs. Based on information from the Annual Reports of the eight largest breweries, the estimation proved a reduction in these costs of ten percent when doubling the size of the brewing groups.
\end{abstract}

Keywords: Advertising, mergers and acquisitions, brewing industry

JEL Classification L11, L66, M37

Presented at the 2013 Beeronomics conference at The University of York and at the International Business and Economy Conference in Tianjin, January 2014 


\section{Introduction}

The early 2000s witnessed a radical concentration in the international brewing industry, as noted by researches and consultancy agents alike, Madsen et al. (2012) and Euromonitor (2010). A significant part of the concentration has been carried by mergers and acquisitions and the impact on market shares has been significant, while so far it seems that positive financial effects are waiting to materialize. While the increasing concentration in the national brewing markets before the turn of the century has been studied in a number of studies for several countries, the globalization of the beer market, where some breweries become global players, has not been dealt with so far.

Increasing economies of scale in plant production has been listed as one of the main factors behind the restructuring of the national brewing industry before the turn of last century; see e. g. Tremblay et al. (2005) and Nelson (2005). However, plant scale economics cannot be the main driver of the globalization of the industry as the international trade of beer is quite low compared to the home production except for a few small countries. If the large number of cross-border mergers and acquisitions that make the industry more global are motivated in a search for larger profit, one has to look at economies of scale at the multi-plant level where management skills, advertising and transfer of know-how or technology become central factors.

In this study we focus on the role of advertising which serves to build brand loyalty. In addition, advertising serves to "premium brands" (which may be premium in no other way than being heavily advertised) thus causing an upward pressure on beer prices. From industrial economics it is well known that the structure of advertising costs translates into significant scale advantages. As observed by Tremblay and Tremblay (2005), the industry has travelled through several stages of development each with its own characteristics. Currently the brewing industry has reached a semiglobal stage reflecting a mixture of global and multi-domestic features, Porter (1986).

The main objective of the paper is to analyze the importance of advertising for the trajectory of concentration in the global brewing industry, by looking at the main large brewing groups and their strategies in brand advertising. Section 2 sets the scene by describing the increasing world concentration in the beer industry and by highlighting some of the driving forces put forward in the literature. Section 3 deals with the role of advertising behavior in the brewing industry and explores the economies of scale in marketing activities. Section 4 and 5 present the empirical evidence for 
economies of scale in marketing both from the US and the global markets. The results verify significant cost savings by scale in marketing and distributions. Section 6 concludes the paper.

\section{Increasing world concentration in mass-produced beer}

After the Second World War the national beer markets for mass-produced beer went through a dramatic restructuring with increasing concentration everywhere. In the US market the share of the four largest breweries increased from 22 to 95 percent in the period 1950-2000 reflecting a decrease in the numbers of independent breweries from above 350 to just 24. The increasing concentration in the market was driven by the growth of a few breweries, where the leading company AnheuserBusch's market share jumped from 6 to 54 percent in the period. For a summary of this development in the US market see Tremblay et al. (2005) and Nelson (2005).

In the last part of the period the so-called microbreweries emerged and their numbers increased dramatically especially in the first part of the 1990s. This segment of the beer market seems to have matured in the US already at the end of the 1990s where their numbers peaked at 1600 in 1998 and has stabilized around that number since then. However, the microbreweries or very small specialty brewers often only brew craft-styled beer on a small scale for local consumers, e.g. the customers of a restaurant, therefore their entry into the industry does not change the concentration measures for the whole industry in any significant way.

As observed by Tremblay and Tremblay (2005), the American industry has travelled through several stages of development in this period and each with its own characteristics, but all driven by increasing economies of scale in production. The minimum efficient scale of a production plant increased steadily throughout the period due to new technology with plant automation that increased the speed of canning and bottling lines. Also the fall in transportation costs increased the economics of plant size as a larger area could be served from a single production plant. As a result they calculate that the American beer market could be served by only 15 efficient firms in 1970 where the actual number of firms where 82. The investment in new technology by the large players create an overcapacity or overhang of inefficient breweries in the industry and a brewing war of attrition for profit in that period, see Iwasaki et al. (2008), who provide evidence of significant effects on the breweries' profit. 
The fast innovation in communication in this period also contributed to the concentration of the industry as it reduces the market for local beer. This is most forcefully documented by George (2009) who looked at the penetration of television in local markets in the US from 1945 to 1960. She found that the numbers of local breweries were negatively correlated with the fraction of the population with access to a television signal and that the opportunity of national advertising through broadcasting accounts for $27 \%$ of the total decline in the market share for the local breweries.

The innovation in production technology and communication in this period forced a concentration in most other national beer markets as well. However, the German markets have lagged behind and Adams (2006) finds that market structure depends on a broad range of factors, extending well beyond the technological opportunity and market size emphasized by Bain (1966). First, he finds that the consumer preference for locally produced beer is much stronger in Germany and therefore it is more difficult to turn the consumer to nationally promoted brands. Secondly, he finds several politically introduced rules which had delayed the restructuring of the industry. The 'purity' rules, which forbid beers to contain preservatives and thereby increase the cost of transportation, were first challenged by the European Court of Justice in 1987 where Germany had to open the borders to beer produced legally in other European Union countries. Also television advertising was more costly due to the limited number of commercial channels and limited amount of time for each add which made it much more costly in Germany to reach the drinking males through television.

The increasing concentration in the national beer markets also reduced the number of competitors at a global scale. However, these developments do not change the cross-border competition very much as the international trade in beer and the cross-border ownership holding were low at that time. The turn of the century changed this as the cross-border mergers and acquisitions increased dramatically and made a few of the breweries real world players, see Pedersen et al. (2013).

Figure 1 highlights this increasing global concentration in the brewing industry after the turn of the century where the four firm concentration ratios increased by 113 percent from a market share of 23 to 49 percent. While the market share for the four largest firms rose by 113 percent, it only increased by 54 percent for the six next largest firms in the industry, so the restructuring of the industry was primarily led by a few large breweries. They became real multinational companies by a strategy of cross-border mergers and acquisitions. The large jump in CR2 of 11 percent in 2008 is the result of InBevs' acquisition of Anheuser Busch. This was a mega takeover amounting to 57 
billion EURO and it made the new company $A B$ Inbev the true leader in the industry with the double size of the next largest company SAB Miller.

Figure 1. Development in concentration ratios in the global brewing industry

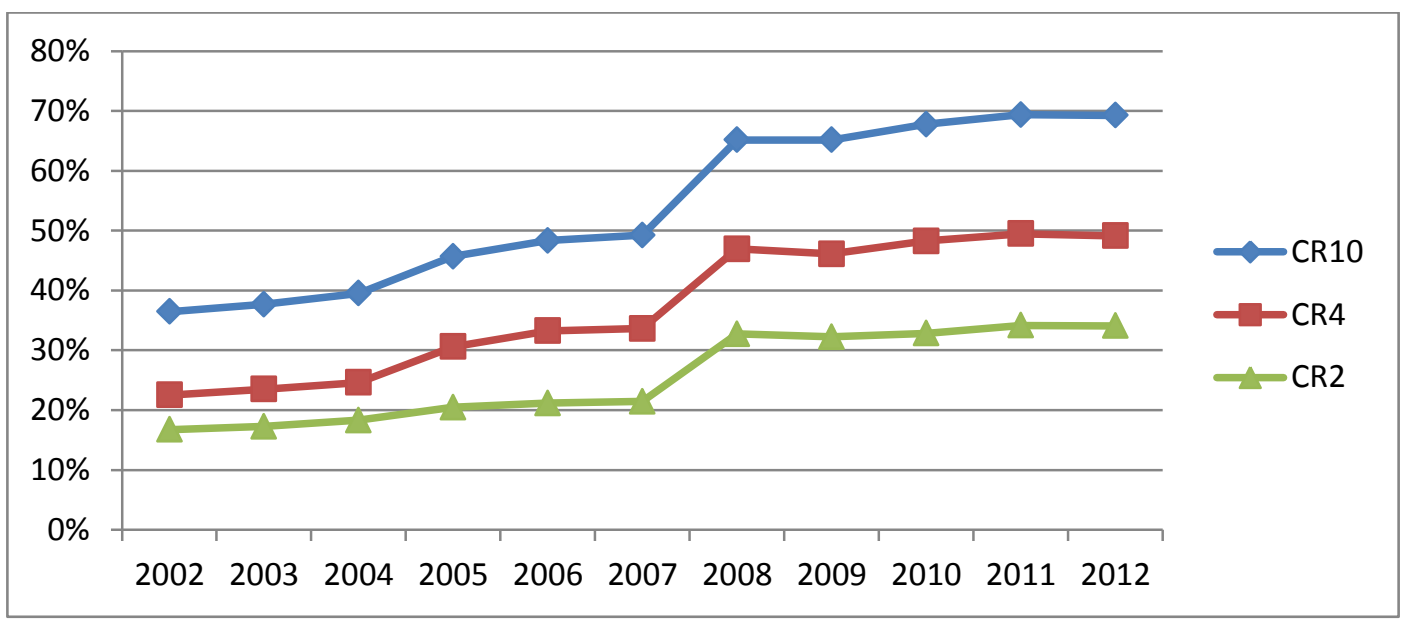

Note: CR2, CR4 and CR10 measure the market share by volume of the two, four and ten largest companies in the worldwide industry.

Source: Market Data Analytics Database.

Although there has been some increase in the market share of imported beer, it still accounts for less than 10 percent in most markets therefore beer is mainly produced locally as the transportation cost is quite high due to the heavy weight of these consumer goods. This excludes economies of plant size as a motivating factor for the wave of cross-border mergers and acquisitions after the turn of the century. If there are any synergies of these strategies, they therefore have to be extracted at a higher level in the company from multi-plant operations or economics of scope in handling several brands. At this level sales and marketing management played a central role as it accounts for a large share of the central costs and we will therefore take a closer look at these costs.

\section{The role of advertising and beer marketing}

The characteristics of beer have not been clearly defined in the literature. As advertising for individual brands exists it cannot be a homogenous good and this leads some authors to conclude that beer is a physically heterogeneous product. However, the product quality or vertical product differentiation do not vary a lot between the brands as the production processes for beer are quite old and have not developed much over the time. The technology is therefore well known and the 
brewing only includes a few raw materials like water, barley, hops and yeast. Most breweries brew the different types of beer like pilsner or lager and the production costs do not vary significantly between the different types.

There is some horizontal product differentiation due to different sorts of barley and hops and the mix of the materials in the brewing process. However, within the same categories of beer the difference in tastes is very moderate and the recognition of brands is therefore often not significant in blind tests. While the real product differences are quite small, the differences in product quality revealed by the beer drinkers are on the other hand very large. This is most forcefully illustrated by McConnell (1968) who made a controlled experiment of the branding effects in the American beer market. He made 24 home deliveries of six-packs of beer over two months to a large sample of beer drinkers. All the beer was identical, so there were no quality differences at all, but the beer drinkers did not know this as the regular labels were removed and new labels were added with three different prices corresponding to the average price of a popular, premium and super-premium beer at that time. When assessing the quality of the beers the panel ranked the high-priced beer higher in quality with a large margin compared to the low-priced beer. One drinker even said about the brand he thought was cheap, 'I could never finish a bottle'.

As the large breweries produce the different variety of beers and even make some adaption to the product to fit local test preferences, it seems that the beer market fulfills the conditions for being a global market, which according to Porter (1986) is a market with a well-defined product, customers with roughly the same needs and the same competitors active in the major markets. However, as there are some small variations in local tastes and long-distance trade and arbitrage are costly, the market has some regional characteristics as well. With a semi-global market for beer and a product with strongly perceived brand preferences of the customers, advertising becomes an important competitive parameter when moving from a national supplier to a global supplier.

The innovation in communication has reduced the costs of advertising due to economies of scale. Especially the emergences of electronic media as radio and television which covers a larger audience and therefore resulted in lower contact costs than advertising in newspapers. Even if the price per viewer is the same for small and large firms, the larger firms then have advantages as they are present in more markets and therefore do not waste advertising on viewers who have no option to buy their product. This is the case for local breweries or smaller national brands which are only present in local shops or bars. As the bulk of advertising moved from the newspapers and other 
printed media to the electronic media which normally cover larger areas, the disadvantages grew for locally based brands.

\section{Some American evidence}

To illustrate the competitive advantages for the large breweries in advertising, we first take a look at the American market. Figure 2 lists the advertising costs in cent per case of 24 beers for the top 3 brewers in the market, and the advertising costs are significantly lower for Anheuser Bush which has a market share significantly larger than the combined share of SAB Miller and Coors. This presents some evidence for economies of scale in advertising.

Figure 2. Development in advertising costs in USD per case for the top 3 brewers

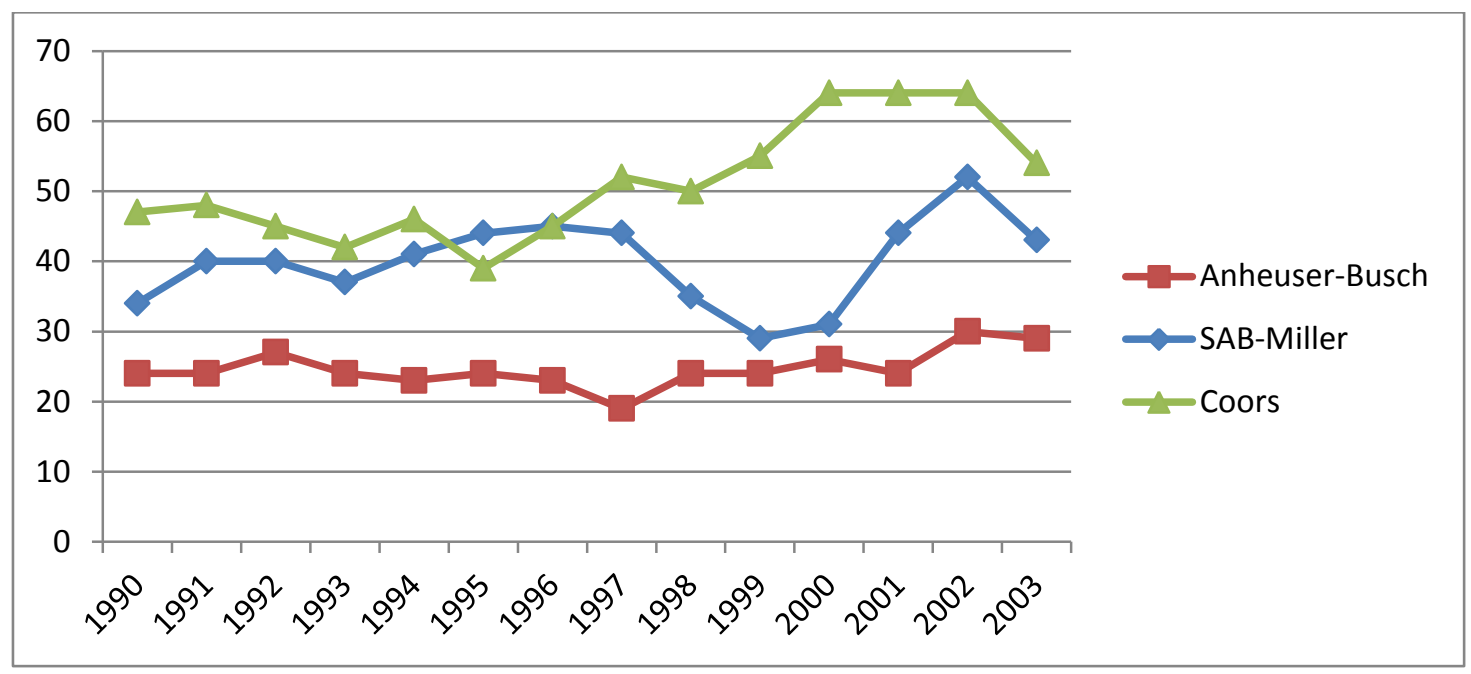

Note: A case is 24 cans or 2.25 gallons.

Source: Nelson (2005), page 278.

From an economic point of view the advertising cost advantages of the larger breweries can also explain their large market share as the larger price-cost margin gives a higher profit motivation to build new capacity as the return on their investments in capacity is larger. However, beside the cost advantages of the larger breweries there is also a strategic advantage compared to the smaller breweries due to a larger total budget for advertising. The market for advertising is not characterized by perfect competition with a well-defined market price. In some cases only one advertiser is selected and there is a strategic game where 'the winner takes it all' and here the deep pocket can make the difference. This is often the situation in advent advertising like sponsorships of 
world championships within sport or the Olympic Games, where deep pockets even is a precondition for participation in auctions of the advertising slots.

To highlight the size-effect of advertising on the cost efficiency and the deep pockets, Table 1 lists estimations for the top 3 breweries in the US in the period 1990 to 2003. The first two models estimate the size effects on the costs of advertising per beer sold. The first model shows that larger breweries have a significantly lower advertising cost per beer sold where a doubling of size reduces the advertising cost with 47 percent. Introducing dummies for Anheuser Bush and SAB Miller in model (2) turns the sign of the size effects from negative to positive. This reveals that the negative size effect emerge from cross-firm effects and that the within-firm size effects in this period are positive and significant. This, of course, is a bit strange, but could either be a result of the inflation in advertising costs or a general rise in advertising in the period due to a more tough fight for market shares. The dummies on the other hand clearly show that even when correcting for size the largest brewery Anheuser Bush still has the largest cost advantages in advertising.

Table 1. Estimation of size effects of advertising and deep pockets in US, 1990 to 2003.

\begin{tabular}{lllll}
\hline Dependent variable & \multicolumn{2}{l}{ Advertising per sale (log) } & $(3)$ & $(4)$ \\
\hline Model & $(1)$ & $(2)$ & 0.910 & $-7.133^{* *}$ \\
Intercept & $6.628^{* *}$ & -1.298 & $(1.801)$ & $(1.194)$ \\
& $(0.267)$ & $(1.887)$ & $0.577^{*}$ & $2.144^{* *}$ \\
Beer sold (log) & $-0.475^{* *}$ & $0.924^{* *}$ & $(0.281)$ & $(0.211)$ \\
& $(0.042)$ & $(0.334)$ & & $-2.425^{* *}$ \\
Anheuser Bush & & $-2.093^{* *}$ & & $(0.315)$ \\
& & $(0.498)$ & & $-3.432^{* *}$ \\
SAB Miller & & $-0.896^{* *}$ & $(0.152)$ \\
& & $(0.241)$ & 0.073 & 0.995 \\
R-square adj. & 0.758 & 0.841 & 42 & 42 \\
Observations & 42 & 42 & & \\
\hline
\end{tabular}

Note: One and two stars indicate a significant level of 5 and 1 percent, respectively.

Source: Data from Nelson (2005), page 278.

The last two models estimate the size effect on the total spending on advertising and model (3) clearly verifies a positive effect where a doubling of firm size increases the budget with $57 \%$. This reflects the economies of scale in advertising as the total budget does not increase proportionally 
and therefore makes rooms for cost efficiencies for the larger brewery. Introducing dummies in model (4) increases the within-firm size effects as in model (2) and probably for the same reason. The model also shows that correcting for firm size effects Anheuser Bush and SAB Miller have a significantly lower total budget for advertising than Coors which mirror the cost advantages.

It is often claimed, that advertising is a useful tool for new firms to enter a matured market as they thereby have an option to inform the customers of their existence and the advantages of their products. However, for some of the big advents as e.g. sponsorships which cover advertising on a global scale it is very expensive and would only pay off if the brewery can serve the whole market and of course, that is a barrier for a new entrant. Further, if they buy their ways into the industry by only one or a few sponsorships, the larger incumbent competitors with the deep pockets and which have several sponsorships and more advertising spots in television will be much more exposed to the consumer and therefore earn a higher brand value and the competitive advantages thereof.

\section{Some world market evidence}

The American evidence of economies of scale in advertising and the globalization in the electronic media raise the question, whether these scale advantages in advertising also cross the national borders and could be taped by multinational breweries. If this is the case, the large wave of mergers and acquisitions within the brewing industry the last fifteen years could be a response to these cost advantages. To answer this question we will look at the eight largest breweries in the world in 2012 and Table 2 shows some simple statistics for the period 2002 to 2012 on their market share and some cost categories.

The costs are reported as share of net revenue and the costs of marketing also include sales expenses as the different types of sales and marketing costs are collapsed in their annual report. However, a lot of the sales expenses in the beer industry have the character of advertising as it is expenses for sales agents and equipment for shops and bars such as desks and refrigerators. Distribution costs are distribution expenses and production costs are costs of goods sold. The breweries use the same terms for the cost categories in their annual reports, but of course, the method for calculating could vary between the breweries. To take care of this heterogeneity in cost accounting, the estimation below used a method with fixed effects for companies as well. 
Table 2. Period average for the 8 largest breweries in the world, $2002-2012$

\begin{tabular}{lcccc}
\hline Company & $\begin{array}{l}\text { World market } \\
\text { share }\end{array}$ & $\begin{array}{l}\text { Marketing costs } \\
\text { (Share in sales) }\end{array}$ & $\begin{array}{l}\text { Distribution costs } \\
\text { (Share in sales) }\end{array}$ & $\begin{array}{l}\text { Production costs } \\
\text { (Share in sales) }\end{array}$ \\
\hline AB Inbev & 0.14 & 0.16 & 0.10 & 0.44 \\
SAB Miller & 0.12 & - & 0.12 & - \\
Heineken & 0.07 & 0.13 & 0.06 & - \\
Carlsberg & 0.04 & 0.19 & 0.13 & 0.50 \\
Molson Coors & 0.04 & 0.29 & - & 0.60 \\
Kirin & 0.03 & 0.15 & 0.04 & 0.51 \\
Tsing Tao & 0.03 & 0.17 & 0.04 & 0.61 \\
Yanjing & 0.02 & 0.10 & 0.02 & 0.61 \\
\hline
\end{tabular}

Note: Share of marketing and sales costs in net turnover. Data from Kirin begins in 2006 and there is no information for marketing in the annual report from SAB Miller.

Source: Cost share from companies' Annual Reports and world market share from Market Data Analytics Database.

The large breweries have many different brands and advertising campaigns are often target to a specific brand. Wilcox (2001) studied beer brand advertising and their market share in the US from 1977 to 1998 . Of the 11 brands studied he only found a significant relation between advertising and market share for 8 brands. However, even if the costs of advertising can be split up on the different brands, the individual brand effects may correlate within the brands of the brewery and then the other brands of the same company, e.g. an advertising campaign for Bud Light may also affect the sales of Budweiser. Therefore the total costs of sales and marketing activities for the brewery is a more precise measure to validate the amount and effects of these activities.

In the period from 2002 to 2012 the concentration in the global market for mass-produced beer more than doubled as listed above, and this restructuring of the industry was mainly driven by high growth among the top 4 breweries which more than doubled their size. To see how this growth in size affects the costs of marketing Figure 3 pictures the development in the share of marketing and sales costs. Of the seven breweries which publish their sales and marketing costs the five experience a fall in this cost share which gives some evidence for the economies of scale in marketing as most of the large brewery groups costs decline. To study these size effects further Table 3 presents the 
results of an estimation of these size effects for both marketing costs and distribution costs using the breweries' world market share as a measure of size.

Figure 3. Development in the share of marketing and sales costs for 7 large breweries

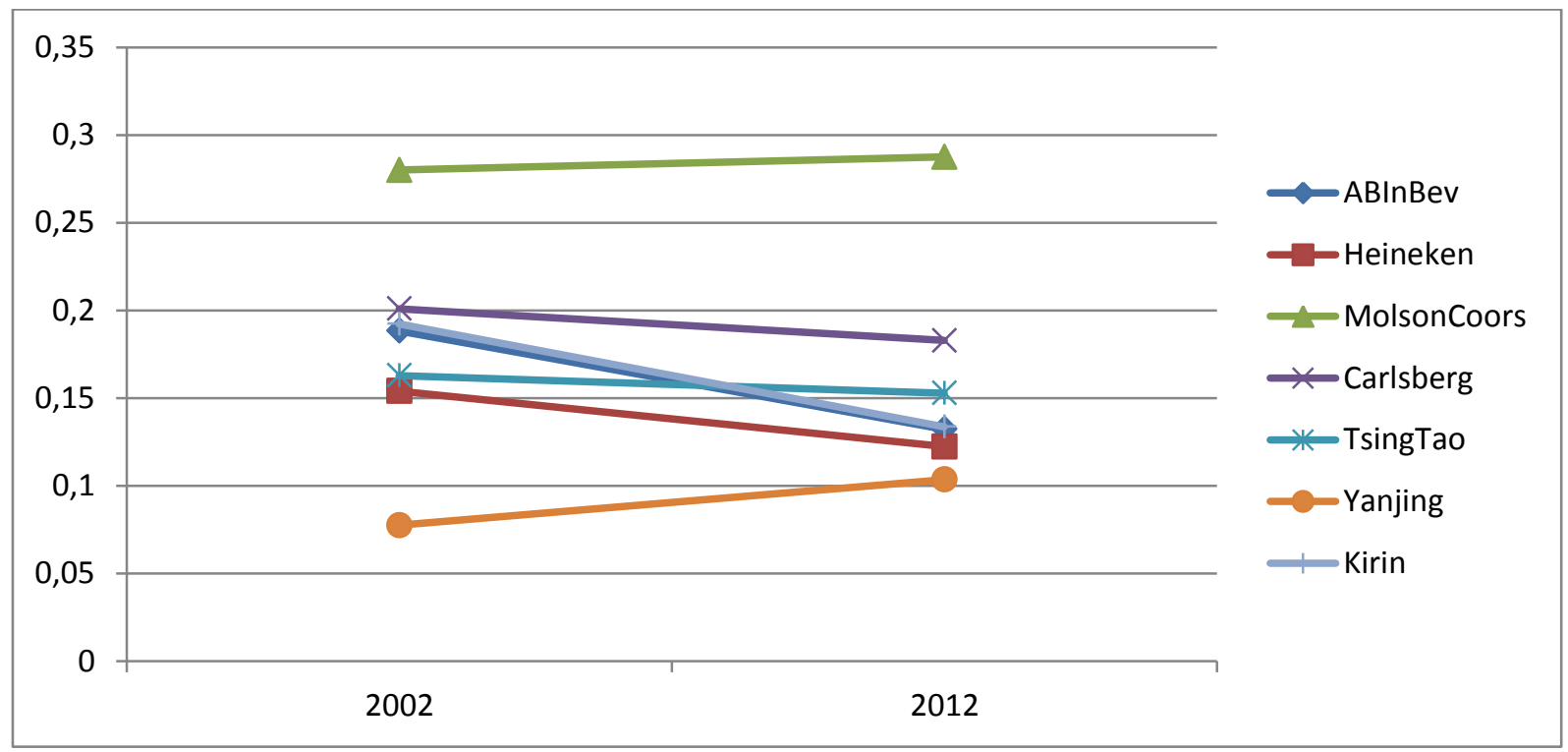

Note: Share of marketing and sales costs in net turnover. Kirin first from 2006 and no information in the annual rapport from SAB Miller

Source: Cost share from companies' Annual Reports.

Table 3. Estimation of size effects in marketing and distribution costs

\begin{tabular}{lllll}
\hline Dependent variable & $\begin{array}{l}\text { Marketing } \\
\text { Cost share }\end{array}$ & $\begin{array}{l}\text { Distribution } \\
\text { Cost share }\end{array}$ & $\begin{array}{l}\text { Marketing } \\
\text { Cost share }\end{array}$ & $\begin{array}{c}\text { Distribution } \\
\text { cost share }\end{array}$ \\
\hline \multicolumn{3}{c}{ Simple OLS } \\
Intercept & $\begin{array}{l}0.176^{* *} \\
(0.011)\end{array}$ & $\begin{array}{l}0.060^{* *} \\
(0.009)\end{array}$ & Fixed effects \\
World market share & -0.151 & $0.285^{* *}$ & $-0.298^{* *}$ & $-0.204^{* *}$ \\
& $(0.156$ & $(0.097)$ & $(0.072)$ & $(0.050)$ \\
R-square & 0.013 & 0.129 & 0.945 & 0.948 \\
Observations & 73 & 60 & 73 & 60 \\
\hline
\end{tabular}

Note: One and two stars indicate a significant level of 5 and 1 percent, respectively.

Source: Cost share from companies' Annual Reports and world market share from Market Data Analytics Database. 
The simple OLS regressions do not show any significant negative size effect but a significant positive size effect in the distribution costs. This may be interpreted as if the smaller breweries on average are as cost-efficient as the larger ones. However, using fixed effects for the breweries the coefficient turns significant negative for both marketing and distribution shares. Thus the withincompany size effect is negative showing that the breweries earn large cost efficiencies when they increase their market share. The size effect is larger in marketing and sales where an increase in the world market share of one percent will reduce the cost share with 0.298 percentage point whereas the cost share for distribution reduces with 0.202 percentage point.

The fixed effect or the heterogeneity between the breweries which makes the smaller breweries more cost-efficient could be the result of different accounting principles as mentioned above. This could be the case for the share of distribution costs which are remarkably low in East Asia. It could also be based on regional differences where branded premium beer has a larger share of the consumption in the developed countries with a matured market and this calls for more sales and marketing costs.

The size effects could also be estimated directly by regressing the cost components on net sales. Table 4 presents the results using a log transformation of the variable. The size effect is of course highly significant in this formulation as the variables are integrated as the cost shares are close to constant. What is in focus, is the size of the coefficient, and where it is below 1 . If so the costs rise less than proportional with sales.

All models have estimated coefficients of a size less than 1. However, in the simple OLS regressions it is not significant below 1, except for the sales costs. But correcting for firm heterogeneity in the fixed effect models, the within-firm size effect is significant below one for both marketing and distribution costs whereas the sales costs are insignificant different from one and the sales costs therefore rise proportional with the increase in net sales. This verifies that the economies of scale in the production have been exhausted so further economies of scale in this period emerged from multi-plant operations. The economies of scale in marketing and distribution are quite large as these costs only increase by about ninety percent when net sales double creating a cost saving of ten percent. As the marketing and sales costs have high cost shares they also return a large gain in costs savings by company growth. 
The large economies of scale in marketing and distribution for the large multinational breweries in the periods after the turn of the century could explain the large wave in mergers and acquisitions in the same period. Further, the investments in branding also represent a sunk cost that creates an entry barrier as discussed above and this creates first-mover advantages in the world market for beers. This opened a competitive race between the large breweries during the 1990s after the rather abrupt opening up of the global market with an increasing concentration and a few large dominating breweries left on the playing fields.

Table 4. Estimation of size effects in marketing and distribution costs

\begin{tabular}{|c|c|c|c|c|c|c|}
\hline $\begin{array}{l}\text { Dependent } \\
\text { variable }\end{array}$ & $\begin{array}{l}\text { Sales } \\
\text { costs }\end{array}$ & $\begin{array}{l}\text { Distribution } \\
\text { costs }\end{array}$ & $\begin{array}{l}\text { Marketing } \\
\text { costs }\end{array}$ & $\begin{array}{l}\text { Sales } \\
\text { costs }\end{array}$ & $\begin{array}{l}\text { Distribution } \\
\text { costs }\end{array}$ & $\begin{array}{l}\text { Marketing } \\
\text { costs }\end{array}$ \\
\hline & \multicolumn{2}{|c|}{ Simple OLS } & & \multicolumn{2}{|c|}{ Fixed effects } & \\
\hline Intercept & $\begin{array}{l}-0297 \\
(0.088)\end{array}$ & $\begin{array}{l}-2.119 \\
(0.549)\end{array}$ & $\begin{array}{l}-1.557 \\
(0.241)\end{array}$ & & & \\
\hline Net sales (log) & $\begin{array}{l}0.969 * * \\
(0.009)\end{array}$ & $\begin{array}{l}0.947 \\
(0.052)\end{array}$ & $\begin{array}{l}0.971 \\
(0.024)\end{array}$ & $\begin{array}{l}0.990 \\
(0.016)\end{array}$ & $\begin{array}{l}0.881 * * \\
(0.047)\end{array}$ & $\begin{array}{l}0.902 * * \\
(0.030)\end{array}$ \\
\hline R-square & 0.995 & 0.850 & 0.958 & 0.999 & 0.995 & 0.997 \\
\hline Observations & 62 & 60 & 73 & 62 & 60 & 73 \\
\hline
\end{tabular}

Note: One and two stars indicate where the coefficients are different from one at a significant level of 5 and 1 percent, respectively.

Source: Net sales and costs from the companies’ Annual Reports.

These first-mover advantages have not materialized in a superior return for the largest breweries compared with the 100 next largest breweries, see Madsen et al. (2012). The reason for this is still unclear, and there are several possible explanations. First, the market power hypothesis where the rise in market concentration increases the market price and the profit for all the breweries in the industry. Next, in the restructuring process of the industry the acquiring companies have to pay a premium for the acquired breweries so most of the synergies from the scale benefit go to the owner of the acquired brewery and leave the acquirer with a larger capital cost. Finally, it may take some time to realize all the synergies from the investment in growth through a merger and acquisition strategy so it has not yet shown up on the bottom line. 


\section{Conclusion}

The opening of the markets in East Asia and Eastern Europe in the 1990s changed the structure of the beer markets and in the following years a large wave of mergers and acquisitions took place. The paper tracks the development in industry concentrations from 2002 to 2012, discusses some of the main drivers behind this development and points to economies of scale in advertising as a main pay-off from mergers and acquisitions.

Using firm-level data both from the American market and the world market, the estimations verify significant economies of scale in marketing and distribution costs. Based on information from the Annual Reports of the eight largest breweries, the estimation proved a reduction in these costs of ten percent when doubling the size of the brewing groups.

These scale advantages in the brewery industry created a playing field on the world market for the breweries after the opening of the new markets in the East where the first movers earn competitive advantages. As the entry barriers for mass-produced beers are high in the world market and the treads from new innovation are low due to the nature of the product these new dominating brewing groups probably can look forward to a long life.

\section{References}

Adams, W. J. (2006). Beer in Germany and the United States. Journal of Economic Perspectives, 20: $189-205$

Bain, J. S. (1966). International Differences in Industrial Structure: Eight Nations in the 1950s. New Haven: Yale University Press.

Elzinga, K. (2005). "Beer”, in The Structure of American Industry. Edited by W. Adams and J. W. Brock. Person Education, 72-95.

Euromonitor (2010). Strategies for Growth in an Increasingly Consolidated Global Beer Market.

George, L. M. (2009). National Television and the Market for Local Products: The Case of Beer. The Journal of Industrial Economics, 57: 85-111. 
Iwasaki, N., B. J. Seldon and V. J. Tremblay (2008). Brewing War of Attrition for Profit (and Concentration), Review of Industrial Organization, 33: 263-279

Madsen, E., L. Lund-Thomsen and K. Pedersen (2012). Effects of the M\&A Wave in the Global Brewing Industry 2000-2010. German Journal of Agricultural Economics, 61/4: 235-43.

McConnell, J.D. (1968). The price-quality relationship in an experimental setting. Journal of Marketing Research, 5: 300-3.

Nelson, J. P. (2005). Beer Advertising and Marketing Update: Structure, Conduct, and Social Cost. Review of Industrial Organization, 26: 269-306.

Pedersen, K., E. S. Madsen and L. Lund-Thomsen (2013). How Mergers and Acquisitions Restructured the International Brewery Industry 2000-10 - And Why? In The Global Brewery Industry - Markets, Strategies and Rivalries. Edited by J. Gammelgaard and D. Dörrenbächer. Edward Elgar.

Porter, M. (ed.) (1986). Competition in Global Industries. Harvard Business School Press, Mass.

Tremblay, V., N. Iwasaki and C. H. Tremblay (2005). The Dynamic of Industry Concentration for U.S. Micro and Macro Brewers. Review of Industrial Organization, 26: 307-324

Tremblay, V. and H.Tremblay (2005). The US Brewing Industry: Data and Economic Analysis. MIT Press, Cambridge, Mass.

Wilcox, G. (2001). Beer Brand Advertising and Market Share in the US, 1977-78. International Journal of Advertising, 20: 149-68. 


\section{Economics Working Papers}

2013-25: Valerie Smeets, Sharon Traiberman and Frederic Warzynski: Offshoring and Patterns of Quality Growth: Evidence from Danish Apparel

2013-26: Torben M. Andersen, Jonas Maibom, Michael Svarer and Allan Sørensen: Do Business Cycles Have Long-Term Impact for Particular Cohorts?

2013-27: Martin Paldam: Simulating publication bias

2013-28: Torben M. Andersen and Allan Sørensen: Product market integration, tax distortions and public sector size

2014-01: Leonie Gerhards and Neele Siemer: Private versus Public Feedback The Incentive Effects of Symbolic Awards

2014-02: $\quad$ Casper Worm Hansen, Peter Sandholt Jensen and Lars Lønstrup: The Fertility Transition in the US: Schooling or Income?

2014-03: Mette Trier Damgaard and Christina Gravert: Now or never! The effect of deadlines on charitable giving: Evidence from a natural field experiment

2014-04: Christina Gravert: Pride and Patronage - The effect of identity on pay-what-you-want prices at a charitable bookstore

2014-05: Julia Nafziger: Packaging of Sin Goods - Commitment or Exploitation?

2014-06: Sylvanus Kwaku Afesorgbor and Peter A.G. van Bergeijk: Measuring multi-membership in economic integration and its trade-impact. A comparative study of ECOWAS and SADC

2014-07: Hristos Doucouliagos and Martin Paldam: Finally a breakthrough? The recent rise in the size of the estimates of aid effectiveness

2014-08: Martin Paldam: The public choice of university organization. A stylized story with some explanation

2014-09: Tor Eriksson, Zhihua Qin and Wenjing Wang: Firm-level Innovation Activity, Employee Turnover and HRM Practices - Evidence from Chinese Firms

2014-10: Erik Strøjer Madsen and Yanqing Wu: Advertising and concentration in the brewing industry 